Who Is Okay? The Harm of One-Dimensional Appraisals of Women Scholars During COVID-19 \& Beyond

Jennifer M. Gómez

Department of Psychology and Merrill Palmer Skillman Institute for Child \& Family

Development, Wayne State University

Center for Institutional Courage 


\begin{abstract}
In this essay, I detail how homogenizing appraisals of diverse faculty women during COVID-19 are harmful to all, including myself. I highlight how academic demands to be "talking heads" and not full human beings, though not new, is especially harmful in the current era. As a Black woman faculty dealing with the double pandemic of COVID-19 and anti-Black racism, the onedimensional appraisals of women faculty exclude me: I am not a mother dealing with sexist overburden in household responsibilities that interfere with my work. Instead, I am dealing with isolation and loneliness, which I sublimate through work productivity. Resulting in shame, I also realize that universities could operate differently, recognizing women scholars for their diversity in identities, backgrounds, responsibilities, work styles, and personalities during the pandemic and beyond. Given that work productivity is not synonymous with well-being, I hope my colleagues know that, in this moment, I am not okay.
\end{abstract}

Keywords: COVID-19, gender equity in academia, cultural betrayal trauma theory, loneliness 


\section{Who Is Okay? The Harm of One-Dimensional Appraisals of Women Scholars During COVID-19 \& Beyond}

I became acutely aware in graduate school that academia can implicitly, yet violently, demand that scholars are one-dimensional talking heads that are separate from our bodies, emotions, life experiences, spirits, and souls. Through providing a space for my full self, the lab of my graduate advisor, Dr. Jennifer J. Freyd, made this institutional demand clear: the rest of academia was clearly not like Freyd's lab (Freyd, 2021). In becoming faculty, I have worked hard to preserve the humanity of my lab and its members, who are graduate and undergraduate students with brilliant minds and even more exceptional souls.

Coming up on a year of actual and ostensible shelter-in-place given the continued spread of the COVID-19 pandemic (Lewis, 2021), I have noticed a crystallization of onedimensionalizing of women scholars: 1) women scholars by definition must be mothers, who are contending with sexist overburden of household responsibilities (Hermann \& Neale-McFall, 2020); 2) women scholars must be behind in their research (Langin, 2021); and 3) women scholars, perhaps particularly those of Color, must caretake their entire department (Shalaby et al., 2021). For me, this latter assertion is true, with departmental caretaking expectation coming from fellow faculty/staff, students, and myself. The emotionally taxing service burden includes giving emotional care to students across the department through emails and meetings, while also providing resources to the department to structurally support students (Gómez, 2020c). What makes the burden heavier is that it feels as if I am doing it alone, with departmental emails urging faculty to please meet with their graduate students...indicating that not all faculty are doing their share of work in supporting their own students, much less all students. 
Given the very public anti-Black racist violence societally (Buggs et al., 2020), I have gained increased sensitivity to the behavioral instantiations of the one-dimensionalizing of women scholars like myself: 1) being excluded from work groups and committees that my expertise and responsibilities suggest I should be on; 2) having others speak for me, both in front of me in meetings and behind my back to others, a la This is what is best for Jennifer; 3) being interrupted and talked over in meetings; 4) being ignored entirely when I speak in a meeting or contribute to an email thread on a departmental listserv; and 5) being blamed by students who perceive me as a cultural betrayer (Gómez \& Gobin, 2020). Borrowed from trauma research, cultural betrayal is the concept that, due to shared marginalization, within-group harm is especially damaging. In academia, cultural betrayal can be felt by marginalized students when I, as a Black woman faculty member, am unable to eliminate their pain due to my incapability of fixing all the structural problems in the department and university. Though I begrudgingly do know that the above are not new, my diminished tolerance for mistreatment amongst all the other life stress makes this behavior towards me especially hurtful. Adding confusion is that, amidst all of this, I am also interpersonally and publicly praised and respected by other members of my department in ways that I cherish due to their genuineness.

A spoken of, but nevertheless relatively overlooked, by-product of the pandemic, is loneliness (Halpert, 2020). Living alone has meant I have not been hugged for 14 months and counting. Outside of brief interactions with strangers while picking up food, taking a walk, or going to the doctor's office, I have, with social distancing, seen only two people in person in over a year, the last being in August 2020. To keep from dissolving into a puddle of tears on the floor of my apartment, I work. 
I work to feel less helpless against all the harms currently highlighted in the world. I work to pass the time. I work to contribute whatever I can through my research on cultural betrayal, sexual violence, and racism (e.g., Gómez, 2015; Gómez, 2020a; 2020b) to help make the world a better place. This sublimation of my pain into work is a longstanding tradition of mine. It is a way I know how to cope.

Yet, I feel shame in sharing my productivity. Shame that I'm not a mother with a family that is taking up my time. Shame that I live alone. Shame that my loved ones do not live in my city. Shame for the unearned privileges of having a job that pays me to do the work I love, while affording me the ability to live in a safe home. Shame that, by being productive, I am making others feel ashamed when they are not as industrious during this time. And fear. Fear that colleagues don’t worry about me because, one-dimensionally, I am doing just fine. And a revisiting of shame when colleagues do reach out, but I set a "Do Not Need You" boundary because the structural problems in academia are so big-I don't need interpersonal support, I tell them, I need you, fellow professor, to carry the weight of this institution with me. But in that push for institutional responsibility, I hide myself from them. And further, I lose myself within the depths of all the pain I carry.

In moments like the present, I know that academia does not have to be this way. Our universities could be places where women scholars were recognized for their diversity in their identities, backgrounds, roles, responsibilities, experiences, work styles, and personalities. To accomplish this, administrators and faculty could engage in institutional courage (Freyd \& Smidt, 2019) by proactively creating a culture and climate that promoted people's full selves at work - mind, body, and spirit. Even after the pandemic is over, women scholars could be known both for their work and their humanity. 
And for now, for me, my colleagues could know that work success is not synonymous with well-being. Because I am more than a talking head, there is more to me than all I have been able to do while isolated at home amidst the double pandemic of COVID and anti-Black racist violence (Stolberg, 2020). While I am confident that I will eventually feel globally happy again, I hope my colleagues ultimately know that, in this moment, I am not okay. 


\section{References}

Buggs, S. G., Pittman Claytor, C., García, S. J., Imoagene, O., Keith, V., Khoshneviss, H., ... \& Roth, W. D. (2020). Systemic Anti-Black Racism Must Be Dismantled: Statement by the American Sociological Association Section on Racial and Ethnic Minorities. Sociology of Race \& Ethnicity, 6(3), 289-291. https://doi.org/10.1177/2332649220941019

Freyd, J. J. (2021). Dynamics Lab Website. https://dynamic.uoregon.edu

Freyd, J. J., \& Smidt, A. M. (2019). So you want to address sexual harassment and assault in your organization? Training is not enough; Education is necessary. Journal of Trauma \& Dissociation, 20(5), 489-494. https://doi.org/10.1080/15299732.2019.1663475

Gómez, J. M. (2015). Microaggressions and the enduring mental health disparity: Black Americans at risk for institutional betrayal. Journal of Black Psychology, 41, 121-143. https://10.1177/00957798413514608

Gómez, J. M. (2020a). Cultural betrayal as a dimension of traumatic harm: Violence \& PTSS among ethnic minority emerging adults. Advanced Online Publication. Journal of Child \& Adolescent Trauma. https://10.1007/s40653-020-00314-0

Gómez, J. M. (2020b). It hurts when you're close: The roles of high betrayal sexual trauma and dissociation in suicidal ideation in young adults. Violence \& Victims, 35, 712-723. https://10.1891/VV-D-19-00150

Gómez, J. M. (2020c). Surviving 2020:Faculty Strategies for Supporting Students During the COVID-19 Pandemic, Increased Anti-Black Violence, Societal/Political Unrest, and So On. https://www.dropbox.com/home/university $\% 20$ of $\% 20$ oregon/research $/ \mathrm{mpsi} / \mathrm{PSYCH} \% 20$ 
DEPT/STUDENTS/FAC\%20SUPPORT/Faculty\%20Support $\% 20$ for $\% 20$ Students $\% 2020$ 20?preview $=$ Faculty + Strategies + for + Student + Support_Gómez Nov $+2020 . p d f$

Gómez, J. M., \& Gobin, R. L. (2020). Black women and girls \& \#MeToo: Rape, cultural betrayal, \& healing. Sex Roles: A Journal of Research, 82, 1-12. https://10.1007/s11199-019-01040-0

Halper, J. (2020, April 2020). How to manage your loneliness. New York Times. https://www.nytimes.com/2020/04/20/smarter-living/how-to-manage-yourloneliness.html

Hermann, M. A., \& Neale-McFall, C. (2020). COVID-19, academic mothers, and opportunities for the academy. American Association of University Professors Newsletter. https://www.aaup.org/article/covid-19-academic-mothers-and-opportunitiesacademy\#.YD93Yi2cZBx

Langin, K. (2021, February 9). Pandemic hit academic mothers especially hard, new data confirm. Science. https://www.sciencemag.org/careers/2021/02/pandemic-hit-academicmothers-especially-hard-new-data-confirm

Lewis, D. (2021, February 23). Superspreading drives the COVID pandemic — and could help to tame it. Nature. https://www.nature.com/articles/d41586-021-00460-x

Shalaby, M., Allam, N., \& Buttorff, G. (2020, December 18). Gender, COVID, and faculty service. Inside Higher Ed. https://www.insidehighered.com/advice/2020/12/18/increasingly-disproportionate$\underline{\text { service-burden-female-faculty-bear-will-have }}$

Stolberg, S. G. (2020, June 7). 'Pandemic within a pandemic': Coronavirus and police brutality roil Black communities. New York Times. 
https://www.nytimes.com/2020/06/07/us/politics/blacks-coronavirus-police-

brutality.html 